\title{
Synthesis and biotical activity of bacterial cellulose 6-(2-phthalimidoethanesulfonate)
}

\author{
C Zoya P. Belousova, ${ }^{1+}$ Pyotr P. Purygin, ${ }^{1}$ Natalia A. Klenova, ${ }^{2}$ \\ Alexandra S. Duyunova, ${ }^{1}$ and Anastasia S. Tryapochkina ${ }^{2}$ \\ ${ }^{1}$ Inorganic Chemistry Department. ${ }^{2}$ Department of Biochemistry, Biotechnology and Bioengineering. \\ Samara National Research University. Moskovskoe Ave., 34. Samara, 443086. Samara Region, Russia. \\ Phone:+7 (846)334-54-45. E-mail: zbelousova@mail.ru
}

* Supervising author; ${ }^{+}$Corresponding author Keywords: bacterial cellulose, 2-phthalimidoethanesulfonic acid, chloride, taurine, antibacterial, antifungal properties, E. coli, Penicillum sp., clotrimazole.

\begin{abstract}
Bacterial cellulose obtained by culturing Gluconacetobacter sucrofermentans in HS environment was converted to sulfonate derivatives using methane-, toluene- and 2-phthalimidoethanesulfonic acids in pyridine. When the ratio of the starting reagents is $1: 1$, the modification of bacterial cellulose according to the primary hydroxyl group of glucopyranose fragments is most likely. The formation of 6-substituted bacterial cellulose derivatives was observed in the reaction mixture. The IR spectra of the reaction products contain absorption bands, which are specific for $\left(\mathrm{O}-\mathrm{SO}_{2}\right)$ group in the region 1377-1338 $\mathrm{cm}^{-1}\left(v_{\mathrm{as}}\right), 1178-1154 \mathrm{~cm}^{-1}\left(v_{\mathrm{s}}\right)$, fragments of the corresponding sulfonic acids, as well as free hydroxyl groups of glucopyranose in the region $3495-3382 \mathrm{~cm}^{-1}$. Bacterial cellulose 2-phthalimidoethanesulfonate was dissolved in pyridine. After drying with a desiccant in a desiccator, it turned into a dense transparent film of brown color. The increased molecular film allows to explain the side reaction occurring between the oxo group and fragments of one of the chains of modified cellulose and the non-substituted hydroxymethyl group. The IR spectrum of bacterial cellulose 6-(2-phthalimidoethanesulfonate) contains absorption bands in the region $1711 \mathrm{~cm}^{-1}$, which are specific for $(\mathrm{Ar}-\mathrm{CO}-\mathrm{O})$ group, and absorption bands in the region $1618 \mathrm{~cm}^{-1}$, which prove the presence of $(\mathrm{CO}-\mathrm{NH})$ group. In order to impart antibiotic properties to the bacterial cellulose 6-(2-phthalimido-ethanesulfonate) film, it was physically modified with clotrimazole. The obtained experimental data showed that the films subjected to treatment with a $1 \%$ solution of clotrimazole have antibacterial and antifungal effects and prevent the growth of pathogenic microbiota on the wound surface. The exit rates of clotrimazole from the bacterial cellulose 6-(2-phthalimidoethanesulfonate) film and from the pure bacterial cellulose film differed, but only slightly. 2-Phthalimidoethanesulfonate bacterial cellulose films can be used to form composites of effective wound covering, since in addition to the unique properties of bacterial cellulose itself (low allergenicity and adhesion to the wound surface, high hygroscopicity) they will have a regenerating effect.
\end{abstract}

\section{References}

[1] J.H. Ha, J.K. Park. Improvement of bacterial cellulose production in Acetobacter xylinum using byproduct produced by Gluconacetobacter hansenii. Korean J. Chem. Eng. 2012. No.5. P.563-566.

[2] D. Klemm, D. Schumann, F. Kramer N. Heßler, M. Hornung, H.-P. Schmauder, S. Marsch. Nanocelluloses as innovative polymers in research and application. Polysaccharides II. Berlin, Heidelberg: Springer. 2006. P.49-96.

[3] I.Y. Shamolina. Prospects of using of microbial raw materials in the production of fibrous and film materials Chemical fibers. 1997. No.1. P.3-10. (russian)

[4] A.V. Pinevich. Miracle Films, or the Word on Bacterial Cellulose St. Petersburg University. 2007. No.3. P.33-99. (russian)

[5] M. Poletto, V. Pistor. Structural characteristics and thermal properties of native cellulose CelluloseFundamental Aspects. 2013. Vol.2. P.45-68.

[6] V.V. Revin, N.A. Klenova, Z.P. Belousova, N.A. Redkin, K.N. Tukmakov, Y.A. Markova. Obtaining and studying the properties of composites based on bacterial cellulose and poly-N,N-dimethyl-3,4methylenepyrrolidinium chloride Izvestiya Vuzov. Applied Chemistry and Biotechnology. 2017. Vol.7. No.1. P.102-110. (russian) 
[7] N.A. Klenova, Z.P. Belousova, E.V. Pisareva, E.V. Vasilieva, Y.A. Markova, A.S. Tryapochkina et al. Composites based on bacterial cellulose produced by Gluconacetobacter sucrofermentas. Actual biotechnology. 2018. No.3(26). P.33-36. (russian)

[8] A.A. Belov, A.I. Korotaeva, E.E. Dosadina, O.E. Malenko, and M.A. Kulemetieva. Medical materials based on modified cellulose, chitosan and multienzyme complex. Butlerov Communications. 2014. Vol.38. No.4. P.42-47. ROI: jbc-02/14-38-4-42

[9] E.E. Dosadina, E.E. Savelyeva, A.Y. Evdokimenko, L.L. Brkich, D.A. Bidanov, E.O. Medusheva, N.V. Pyatigorskaya, G.E. Brkich, and A.A. Belov. Prolonged biomedical materials based on modified cellulose. Butlerov Communications. 2017. Vol.50. No.5. P.109-117. DOI: 10.37952/ROI-jbc-01/17-50-5109

[10] Cellulose and its derivatives. Study of the structure of cellulose and its derivatives. Ed. Bikleza N., Segala L. Vol.I. Mir Publishing House. Moscow. 1974. P. 54-119. (russian)

[11] J. Das, A. Roy, C.P. Sil. Mechanism of the protective action of taurine in toxin and drug induced organ pathophysiology and diabetic complications: a review. Food \& Function. 2012. Vol.3. No.12. P.12511264. doi:10.1039/c2fo30117b.

[12] S.W. Schaffer, J. Azuma, M. Mozaffari. Role of antioxidant activity of taurine in diabetes. Can. J. Physiol. Pharmacol. 2009. Vol.87. P.91-99.

[13] L. Pellegrino, R. Cocchiola, I. Francolini, M. Lopreiato, A. Piozzi, R. Zanoni, A. Scotto d'Abusco, A. Martinelli. Taurine grafting and collagen adsorption on PLLA films improve human primary chondrocyte adhesion and growth. Colloids and Surfaces B: Biointerfaces. 2017. Vol.158. P.643-649. doi:10.1016/ j.colsurfb.2017.07.047.

[14] M. Farooq, S. Sagbas, M. Sahiner, M. Siddiq, M. Turk, N. Aktas, N. Sahiner. Synthesis, characterization and modification of Gum Arabic microgels for hemocompatibility and antimicrobial studies. Carbohydrate Polymers. 2017. Vol.156. P.380-389. doi:10.1016/j.carbpol.2016.09.052.

[15] J. Humljan, M. Kotnik, A. Boniface, T. Solmajer, U. Urleb, D. Blanotc, S. Gobeca. A new approach towards peptidosulfonamides: synthesis of potential inhibitors of bacterial peptidoglycan biosynthesis enzymes MurD and MurE. Tetrahedron. 2006. Vol.62. P.10980-10988.

[16] H.R. Kricheldorf, E. Leppert. Synthese von Peptiden des Taurins und der Sulfanilsäure. Synthesis. 1976. Vol.1. P.43-45. doi:10.1055/s-1976-23954.

[17] R. Winterbottom, J.W. Clapp, W.H. Miller, J.P. English, R.O. Roblin. Studies in Chemotherapy. XV. Amides of Pantoyltaurine. J. Am. Chem. Soc. 1947. Vol.69. No.6. P.1393-1401. doi:10.1021/ja01198a047.

[18] N.D. Afonina, L.N. Erofeeva, S.S. Voronkina. Development and validation of a method for quantitative determination of clotrimazole in medicinal films for the treatment of otomycosis. West. Mosk.

University Ser. 2. Chemistry. 2013. No.1. P.68. (russian) 